\title{
Mapping and Geovisualizing Topographical Data Using Geographic Information System (GIS)
}

\author{
Ndidi Felix Nkeki ${ }^{1} \&$ Monday Ohi Asikhia ${ }^{1}$ \\ ${ }^{1}$ Department of Geography and Regional Planning, University of Benin, Benin City, Nigeria \\ Correspondence: Ndidi Felix Nkeki, Department of Geography and Regional Planning, University of Benin, \\ Benin City, Nigeria. E-mail: nkekifndidi@gmail.com
}

Received: November 30, $2013 \quad$ Accepted: December 26, $2013 \quad$ Online Published: January 16, 2014
doi:10.5539/jgg.v6n1p1
URL: http://dx.doi.org/10.5539/jgg.v6n1p1

URL: http://dx.doi.org/10.5539/jgg.v6n1p1

\begin{abstract}
The mapping and visualization of topographic setting is paramount for the understanding and management of the physical environment. Based on this, sophisticated method that produces accurate result must be adopted to ensure that the right decision is made during planning. GIS technique has proved itself to be a force for sustainable development that is why researchers worldwide frequently apply its procedures in their investigations. The application of GIS in landscape mapping and visualization has increased the confidence ascribed to contemporary cartographic output. However, the primary objective of this paper is to demonstrate how GIS method can be used to simulate topographical data by applying various cartographic techniques in Edo State. DEM-based topographic data of the study region was entered into various GIS softwares and algorithms for manipulation and extraction of terrain features. Progressively, vital topographic features were automatically extracted and generated, these were used to build a GIS-assisted topographical database consisting of such physical features as the stream network of the region, stream catchment, contour and spot height, slope and relief direction etc. From this database, suspicious landscape structure was identified in the region. These digital derivatives are essential for the understanding of the region's landscape for the purpose of further investigation, planning and policy making.
\end{abstract}

Keywords: geovisualization, geographic information system, DEM, landscape profiling, topography, geospatial, GIS

\section{Introduction}

A geographic information system (GIS) allows physical geographers and other landscape researchers to investigate spatial patterns within their earth surface data and understand the relationships that exist between the physical environment and human activities. The power of visualization cannot be excluded in spatial pattern assessment and this merit is one of the fundamental character of GIS. Initially, cartographers encountered difficulty in mapping the landscape and displaying the preceding result in a manner that make sense pertaining to accuracy and level of coverage. Cartography as commonly defined is the art, science and technology of making maps (ICA, 1973), the latter must be presented in more alluring format to aid interpretation and understanding. Otherwise, the art, science and whole processes involved in making such map will be meaningless. This is because without doubt, cartographers depend on visual tools to accomplish their task (Brewer, 2006).

The advent of GIS and latest advancement in its associated technologies have revolutionized the entire processes of mapping and visualizing topographical data. The proper integration of GIS and it associated technologies such as remote sensing, have opened up new frontier often termed 'geospatial' which has so far proved helpful in solving geographic problems and identifying geographic locations. Geospatial refers to the data and technologies use to identify geographic location and explore its problems. The concept "geographic location" in this paper, generally includes well-defined formal regions like countries, states and local government areas; natural areas like watershed, mountain ranges, valleys that can sometimes be formally defined based on their observable features; and ill-defined sociocultural regions like neighbourhoods.

Before the introduction of GIS technology, cartographers relied heavily on data derived from conventional survey to produce topographical maps which were largely interpolated with contour lines, and manually produced hill shaded maps (Alpha \& Winter, 1971; Imhof, 1965). This crude method has been disparaged for it tediousness, less cost- effective, time consumption and less accuracy (Collier, 2002; Ozah \& Kufoniyi, 2008). 
The manual method of topographic mapping and visualization can no longer satisfy the contemporary planning needs pertaining to the quality and quantity of spatial information. However, the tremendous role that topographic map play in national development has been recognized in many advanced countries of the world. This is basically the reason behind the huge investment in technology both in data collection, manipulation and geovisualization. Thus, this has motivated researchers in such countries to regularly conduct fresh topographic mapping using the latest spatial dataset and sophisticated technology (Ehsani \& Quiel, 2009; Yokoyama et al., 2002; Wu et al., 2007; Hirano et al., 2003; Lindsay \& Creed, 2006).

In developing countries, the lack of reliable topographical data for greater part of such countries generally hinders topographic mapping and modeling (Valeriano et al., 2006). This deficiency is common with Africa countries like Nigeria, where poverty and inadequacy in technological advancement in the aspect of geospatial information has resulted in the inability of such countries to regularly produce new topographical map especially on a wider scale (Ozah \& Kufoniyi, 2008). Importantly, because topographical information is fundamental to a large variety of environmental planning and resource management (Ehsani \& Quiel, 2009; Ludwig et al., 2000; Ludwig \& Schneider, 2006) most of these countries resort to utilizing existing topographic map which are very old and out of date. More importantly, these maps are stored and visualized using map sheets which often limit further manipulation and integration.

In Nigeria, a plethora of literatures in this area are dedicated to topographical map revision using existing base map (contour), in some cases, aerial photographs, satellite imageries and GPS (Okpala-Okaka \& Igbokwe, 2010; Ufuah, 2002, 2003; Obot, 2005; Petrie, 1997; Adesina, 2007; Ajayi, 1992; Atilola, 1990; Olaore, 2007). This method of producing new topographic maps (usually by integrating existing topographic map with spatial data from aerial photograph, satellite images) is often cumbersome, time consuming and error-prone because of the discrepancy that exist in the base map and new dataset. For example, most manually derived contour maps have intervals largely different from the satellite derived dataset. This is because conventionally produced contour maps are highly generalized and intrinsic relief information may have been lost during the process of printing, scanning and digitalization.

The use of sophisticated GIS softwares to map and visualize high resolution space derived data such as the Shuttle Radar Topography Mission (SRTM) digital elevation model (DEM) will significantly reduce the problems associated with topographical map revision, cut down cost of producing relief maps, improve the level of accuracy and a better visualization platform. Moreover, this technique will undoubtedly simplify complex topographic data for planners and policy makers through its geovisualization platform.

GIS technology has made topographical mapping and geovisualization more accurate, appealing and a large area can be mapped within a far lesser time frame. It has the power to visualize geographic data by allowing the user to dynamically integrate multiple data sources, unconstrained by format, scale and coordinate system. Also, the capability of GIS technology to visualize and analyze spatial and non-spatial information from diverse sources makes it a powerful platform for multilevel decision making, and so greater credit should be given to its geovisualization capabilities. They enable a large volume of geographic data to be summarized into a map which, without doubt, facilitates fast visual interpretation (Nkeki, 2013a). In this paper, GIS technology is viewed from two dimension-the spatial data gathered with sensor-based space satellite devices used for producing topographic maps such as DEM and those used for manipulating and geovisualizing the DEM data such as GIS softwares and algorithms. Geovisualization (geographic visualization) refers to the technologies and procedures of displaying geographic data for quick visual interpretation. Presently, this method of visualizing geographic dataset is fast replacing the cumbersome paper topographical map. It is capable of visualizing multiple spatial data and presents a friendly interface between the map and the user.

However, GIS was initially loosely perceived as a set of computer tools for making maps. Clarke et al. (1996) defined it from the perspective of its functional capabilities as a tool that can bring together the elements necessary for problem solving and analysis. GIS is actually a complex and powerful state-of-the-art technology beginning with automated modeling of landscapes captured by cameras, digitizers or scanners. In advanced cases such models can be transmitted by satellite, and with the aid of computer systems they can be manipulated, enhanced, analyzed, visualized and stored as data referenced to the earth (Nkeki, 2010).

The sensors onboard the space satellite device is capable of generating extremely high detailed 3-dimensional models of the earth's surface. DEM data has revolutionized the process and quality of topographical maps generation (Ozah \& Kufoniyi, 2008). When properly manipulated with the right GIS algorithm, DEM data can display not only the 3-dimensional (X, Y and $\mathrm{Z}$ ) attribute and non-attribute data of the landscape but also the river network, nodes, watershed, flow direction and other numerous topographic and hydrographic features. The 
use of DEM for mapping and visualizing landscape has become a prominent tool among scientific researchers across the continents of the world (e.g., Jordan et al., 2003; Ganas et al., 2001; Michetti et al., 2001; Vysotsky et al., 2002). The fundamental merits of using GIS technology for mapping and geovisualizing topographic data as against the ground-based or conventional survey method, is that it appears far less tedious; more accurate (because it provides the platform for interpolation and correction); wider coverage (can gather data worldwide, even in the most remote and rugged terrain region); it presents the opportunity to integrate and compare multi-dimensional data (Valeriano et al., 2006; Asikhia \& Nkeki, 2013; Ozah \& Kufoniyi, 2008).

Fundamentally, this paper simulates the landscape of Edo State using DEM-based grid data within the GIS environment. In addition, the stream network, watershed and other terrain features were extracted and mapped with powerful GIS algorithms, softwares and geovisualization tools. These features were used to create a topographical geodatabase for the area. Such database, may play a vital role in the aspect of spatial planning especially accessibility related (road, pipeline and rail network construction). The measure of confidence ascribed to a GIS derived database is very high, this can be linked to its spatial framework and methodology. It ability to model the real world scenario with data correspondingly collected from the real world makes its output and result empirically viable and reliable for further scientific investigations (Nkeki, 2013b).

\section{Study Area}

The study area is Edo State located in the south western part of Nigeria between latitude $5^{\circ} 44^{\prime} 60^{\prime \prime} \mathrm{N}$ to $7^{\circ} 33^{\prime} 45^{\prime \prime} \mathrm{N}$ and longitude $5^{\circ} 05^{\prime} 45^{\prime \prime E}$ to $6^{\circ} 38^{\prime} 18^{\prime \prime E}$ (Figure 1). It covers an area extent of about $19,853 \mathrm{~km}^{2}$. The state is made up of 18 local government areas (LGAs) and a total population of 3,233,366 (based on the 2006 National Population census). The region has a low land of roughly $16,992 \mathrm{~km}^{2}$ and high land of approximately $1,586 \mathrm{~km}^{2}$ (Fabiyi et al., 2012). Basically, the topography of the state is consist of a rugged high land in the north which extended down to the central part of the region. The high land is dissected by a wide valley which stretches from the Niger River floodplain in the east to the western margin of the state. In the south, the topography is a gentle sloping plane that extends into Delta State.

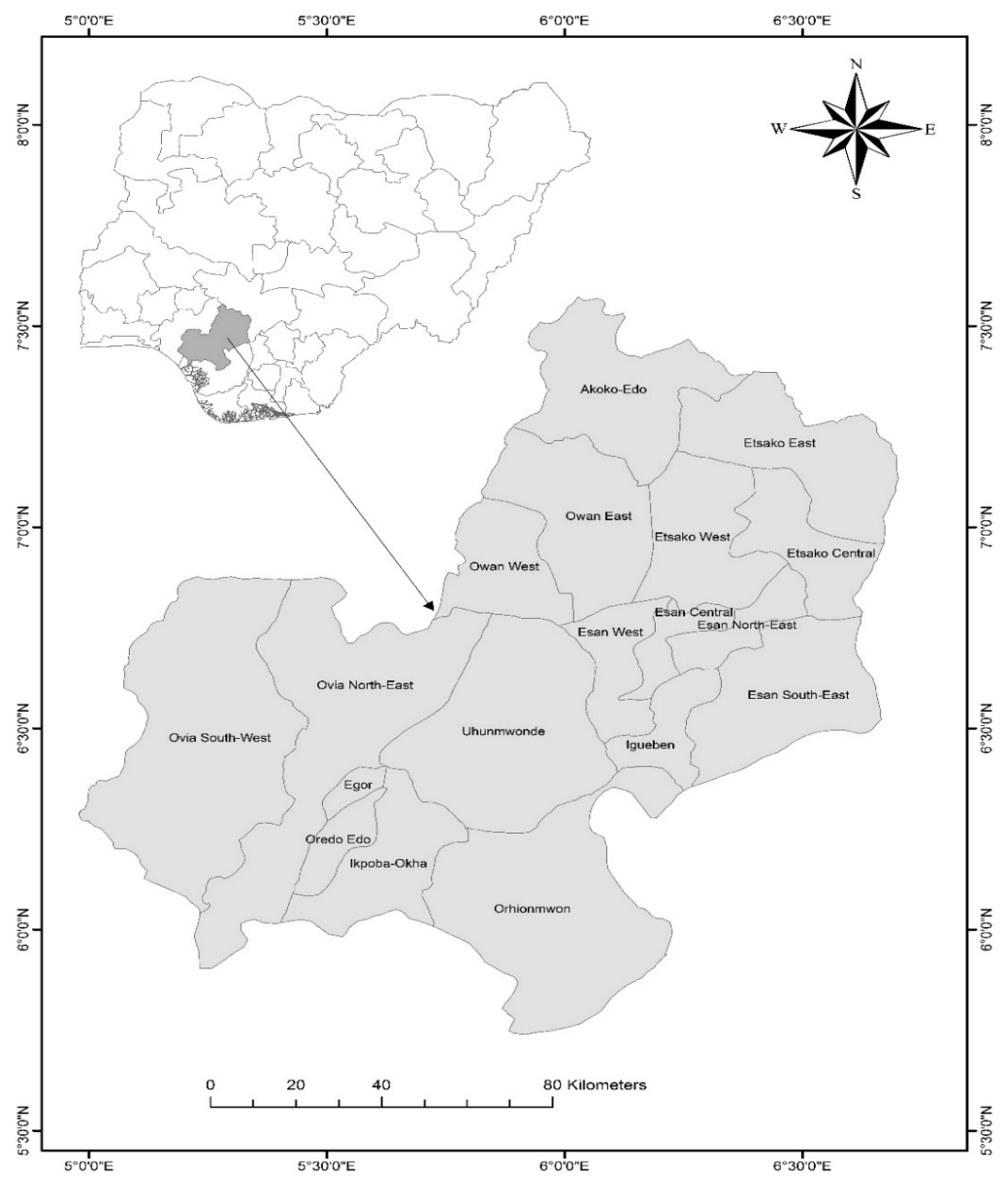

Figure 1. Location of the study region 


\section{Data}

The use of earth observation system technology and GIS platform has become an integrated, well developed and reliable approach in geographic analysis (Nkeki et al., 2013). As a result, this paper utilized a $90 \mathrm{~m}$ spatial resolution DEM created by SRTM. The SRTM digital elevation data, originally produced by National Aeronautics and Space Administration (NASA) is a major advancement in digital terrain mapping and provides free and easy access to high quality elevation data for researchers. This digital dataset is available for download from U.S. Geological Survey's EROS data center's website.

The SRTM high resolution DEM with 3 arc-seconds (90 m resolution) mosaiced of 1 degree by 1 degree tiles that was used in the topographical mapping is composed of several tiles (which covers the study area). The DEM dataset has been mosaiced into seamless near-global coverage (up to 60 degrees north and south) and converted to various raster formats. The dataset has been preprocessed to fill in the voids in the version 4.1 with improved hole-filling algorithm which makes use of ancillary data sources and presented in geographic coordinate system, WGS84 datum. The SRTM using a dual-antennae, single-pass interferometric synthetic aperture radar (INSAR) operating at a wavelength of $5.6 \mathrm{~cm}$ (C-band), has produced the most accurate near-global DEM covering most land and adjacent near-shore ocean areas (Farr \& Kobrick, 2000; Rabus et al., 2003; Carabajal \& Harding, 2006).

\section{Material and Methods}

To ensure maximum accuracy in the topographic mapping and geovisualization, various sophisticated and most recent GIS softwares and algorithms were utilized. They include ESRI ArcGIS version 10.1, Global mapper version 13.0 (developed by Blue Marble Geographics), Surfer surface mapping system version 11.0.6 (developed by Golden software Inc), ESRI Arc hydro version 1.4, HEC-Geo Dozer version 1.0 and HEC-Geo HMS version 5.0. The HEC-Geo Dozer and HEC-Geo HMS are algorithms design as extension for Arcmap by US Army Corps of Engineers Hydrologic Engineering Center. The tools were designed specifically to edit terrain data and improve stream and watershed delineations.

Creating the DEM for the analysis requires merging the SRTM DEM tiles into one raster grid entity (mosaic raster assembly). Progressively, the tiles were entered into the ArcMap-ArcInfo platform for processing. Using the DEM assembly tool of HEC-Geo Dozer, the tiles elevation data were merged into a terrain feature and then resampled to create a composite raster hydro DEM of the region (Figure 2). Although it would have been possible to exclusively use a 5-degree single tile which covers the full extent of the study area, the 1 degree tile was used in order to capture the low relief features of the area so as to achieve a maximum visualization capacity in the result. The generated hydro DEM was transformed from geographic coordinate system to projected coordinate system (i.e. from GCS-WGS1984 to WGS1984 World Mercator).

The GIS approach to topographical mapping requires a DEM that is spatially corrected. Such corrected terrain model is one in which all depressions have been filled (HEC-Geo Dozer, 2009). The fill sinks algorithm was applied to modify the elevation value to ensure that the water trapped in the cells surrounded by higher elevation cells are released and allowed to flow. However, the resampled DEM in grid format was clipped to the actual shape and size of the study region using the extract by mask tool of the spatial analyst tool box in Arcmap (Figure 2).

\section{Results and Discussion}

With respect to the purpose of this paper, popular methods of geovisualizing topographic data were mapped using GIS algorithms accordingly to automatically extract such surface features from the SRTM grid DEM. These methods comprise contour lines and spot height, shaded relief, aspect and slope direction, cross-section profiling, stream network, watershed and 3-dimensional simulation model of the region's terrain.

\subsection{Contour Line and Spot Height}

The use of contour line and spot height for mapping topographical characteristics has been the most effective and widely accepted method of represent relief before the advent of DEM-based data. It represent elevation and landscape slope gradient simultaneously. The slope gradient is determined by the density or spatial clustering of the contour lines along a strip. The elevation is represented by the height value assigned to the lines mostly in meter above the sea level. Contour line is often insufficient in mapping fine topography and flat surface. For a detailed representation, contour lines are usually integrated with spot height. This is because the ground based survey method for collecting data used for making contour maps is highly interpolated and generalized. The use of DEM to generate contour map is fast gaining popularity and wide spread usage based on the stark reality that it is more accurate and the generation process is automatic. Spot height is the elevation value of a particular spot within the set terrain, it is incorporated into the contour map to improve the accuracy of the map. 


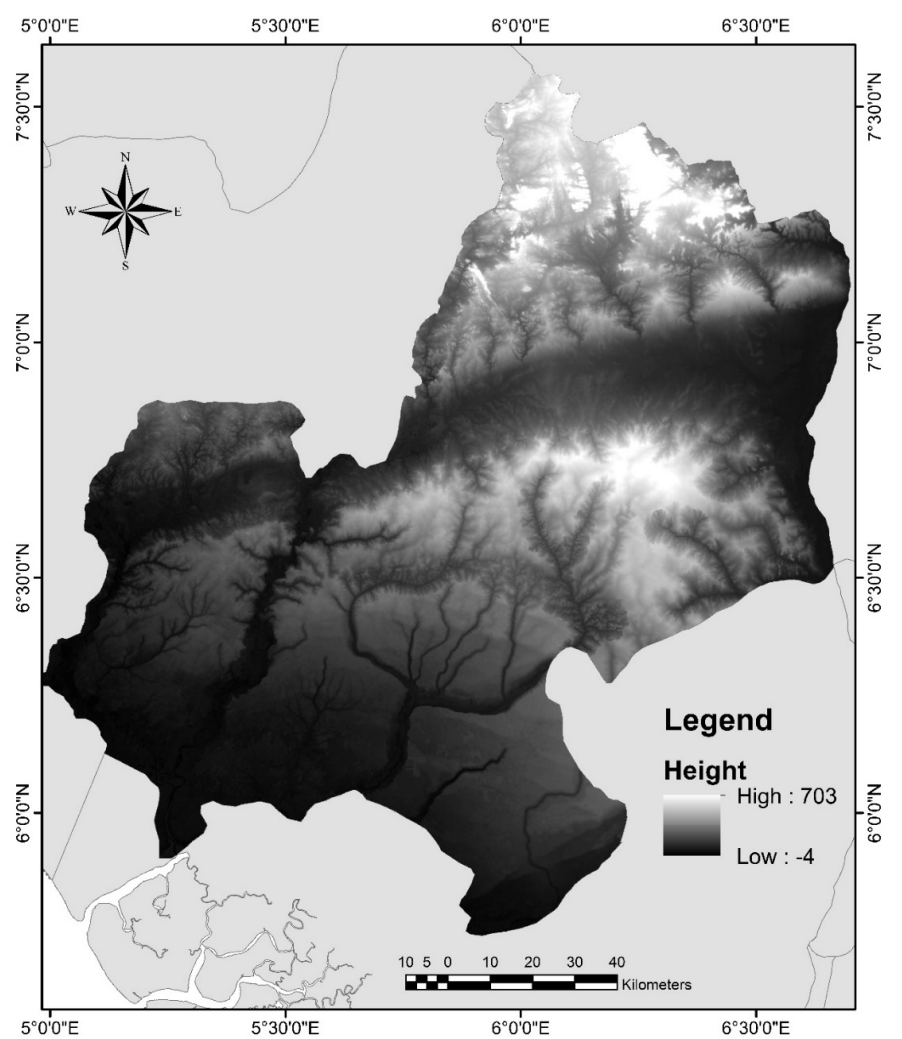

Figure 2. SRTM mask resampled DEM of Edo State

Figure 3 shows the contour and spot height map of the study region. The density of contour lines in the north and central part of the area indicate the ruggedness of the landscape. A cursory examination of the map shows that generally, there is hierarchy in the topography with reference to height and ruggedness of the relief. The south is typically a low land area while the north on the hand is basically a high land region. An intermediate category is located in the central part of the map. The contour map reveals a wide valley which created a distinct dichotomy between the northern and central relief. In the map, the highest and lowest point is depicted with spot height. Spot height for the highest point in the region is 690.5 meters above sea level (see the zoom section in Figure 3 for details). The lowest point is found in the south western margin of the region, its spot height value is 0 meter above sea level.

\subsection{Stream Network and Watershed Mapping}

The overall stream network of the study area was mapped using the resampled SRTM dataset. The extraction process identified all the cells of the DEM that ultimately drained to the specified outlet location and the stream network created determined the channels for the watershed. The result of this procedure is the generation of a flow direction grid, which defines the slope (and hence flow direction) of each cell. This grid is fundamental in the generation of all watershed, including the flow accumulation grid that was used to define the stream network. Basically, the flow accumulation grid is computed with an algorithm that aggregates the contributing upstream area for each cell.

For better visualization and further calculation, the flow accumulation grid was subjected to stream definition (visualization) and segmentation algorithms. The stream definition is based on a specified threshold that is usually applied to reveal the stream length. In this case the threshold value of the contributing source area for flow characterization was set at 10850 numbers of cells. These procedures assisted in the automated extraction of the overall drainage line features which consists of 568 streams. Progressively, 586 watersheds were equally extracted and mapped (Figure 4). 


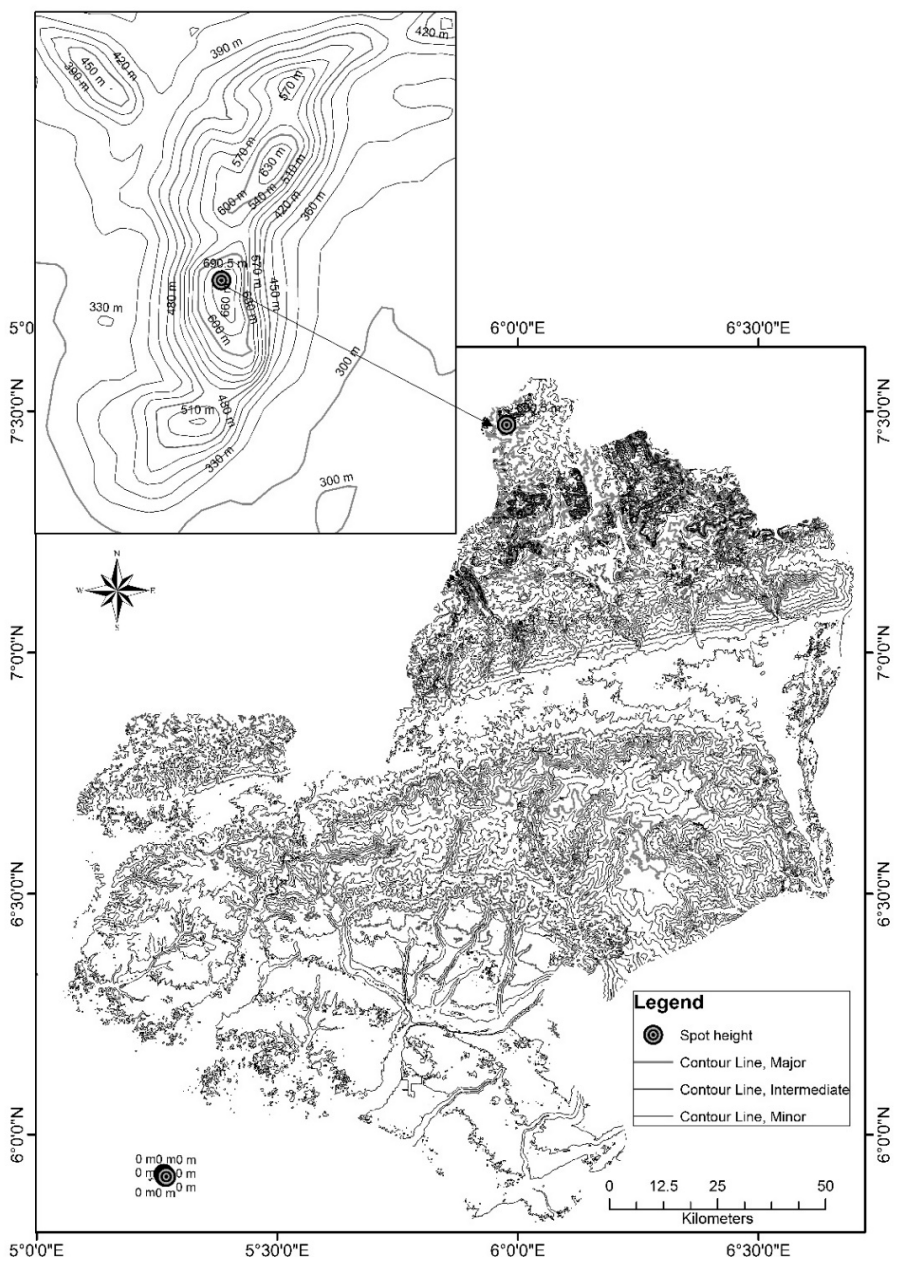

Figure 3. Contour and spot height of the study area-contour interval is set to 30 meter consequently, terrain below such height in the south is left plain

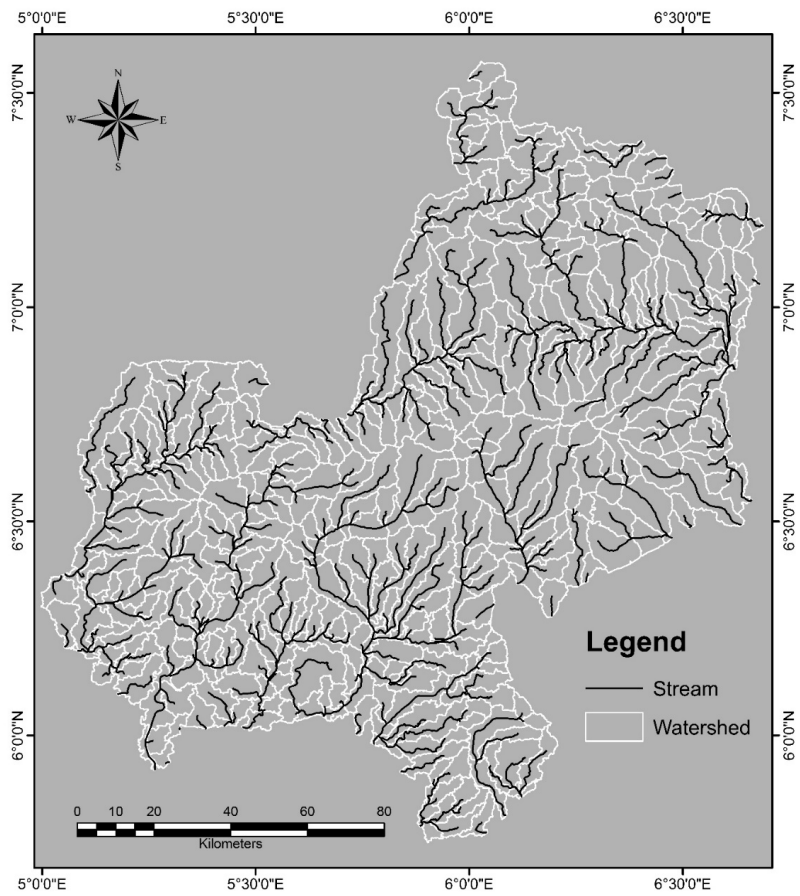

Figure 4. Stream network and watershed of the region 
Figure 4 is an overlay of the stream lines vector and the watershed polygons. This map will be helpful when there is need to study the hydrographic terrain of the study area. In most cases, it is utilized for planning agricultural activities and more importantly, it is an indispensable tool for monitoring and tracking down sources of stream pollution. The longest flow path is $43 \mathrm{~km}$ and the drain area covers $194.7091 \mathrm{~km}^{2}$, its midpoint is location between $6^{\circ} 43^{\prime} 57.537 \mathrm{~N}$ and $5^{\circ} 8^{\prime} 23.817^{\prime \prime E}$. Correspondingly, the largest watershed occupies an area of $195 \mathrm{~km}^{2}$ and a perimeter $110 \mathrm{~km}$, it midpoint has the same geographic location as that of the longest flow path.

\subsection{Shaded Relief, Aspect and Slope Direction}

Shaded relief is also a popular geovisualization technique for topographic data. It displays topographic features by simulated shade which is calculated using incident light direction and elevation data (Chiba et al., 2008). The fundamental merit of this method is that the details can easily be comprehended through quick visualization. However, shape and direction of shade depends to a large extent on the bearing of the incident light. Figure 5 shows an overlay of the shaded relief grid and the extracted stream network of the region's topography. From this map it is possible to visualize the terrain of the area in 3-dimension. The manner in which the stream network feature fits into the 3-dimensional shaded relief feature reveals the level of accuracy of the method. However, the shaded relief uses shadings to show the nature of the landform such as river valleys and dry valleys, uplands and lowlands feature. Most interestingly, the elevation hierarchy detected by contour line map became clearer and present an appealing visual impression. This map will serve as aid for further geological study and help ask empirical research questions about suspicious characters and irregularities in the landscape. Example of such question is concerning the large valley running from the eastern to western part of the region.

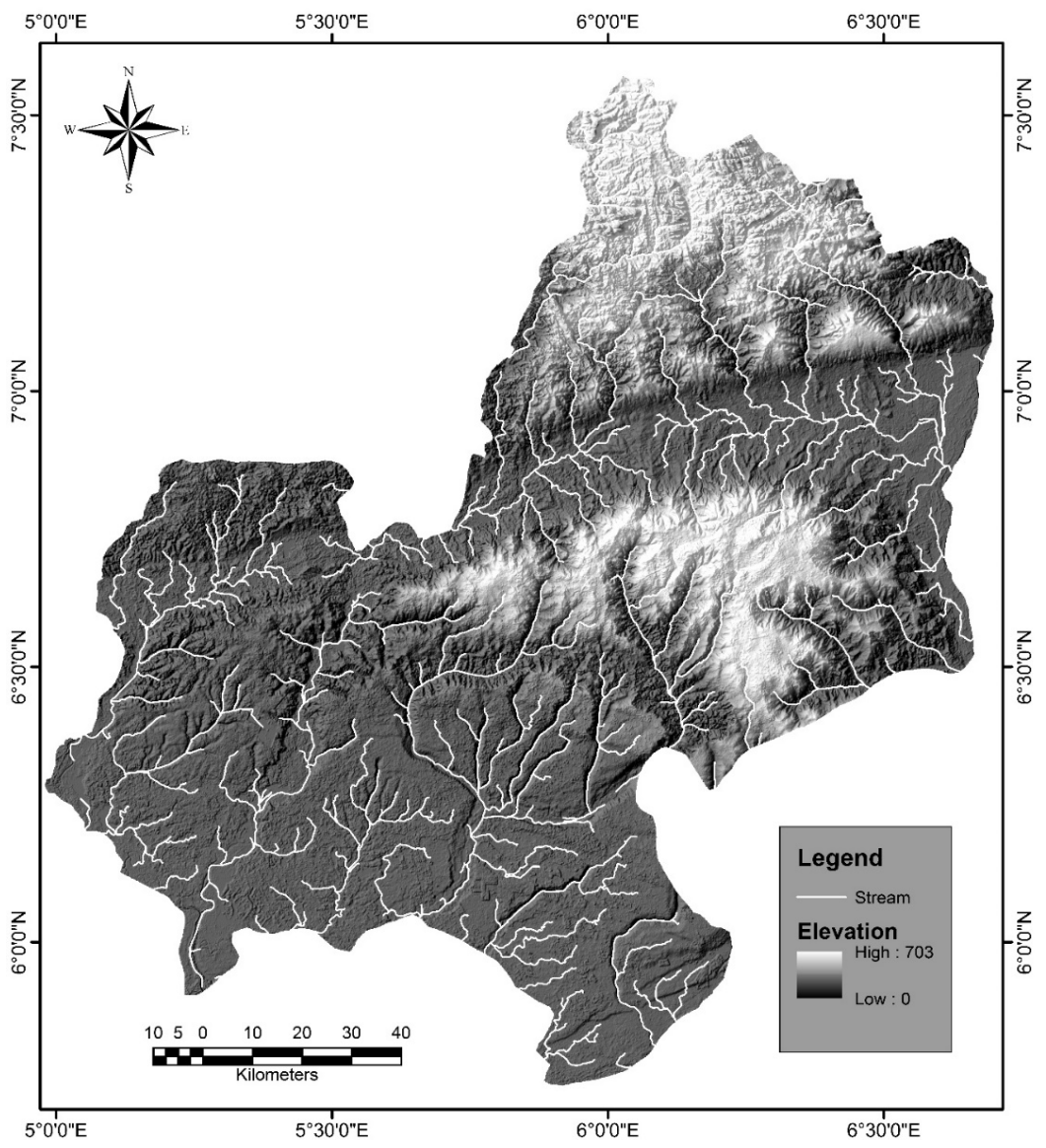

Figure 5. Shaded Relief grid image of Edo State-It was generated with Azimuth $315^{\circ}$, Altitude $45 \mathrm{~km}$ and Z factor 10x. The stream vector is overlayed on the relief grid

Aspect detects the downslope or downhill direction of the maximum rate of change in value from each cell to its neigbhours. It is often referred to as the slope direction. At a particular location a value is generated for the cell and this value indicates the compass direction of such slope. The aspect of a terrain is measured clockwise (in 
degrees) from $0^{\circ}$ which is the north through northeast and move to the north again through the northwest which complete $360^{\circ}$. In Figure 6, the slope facing north to northeast are presented in dark shades while those facing north to northwest are light shades. Flat areas have no downslope direction as a result, they are assigned the value of -1 and represented with the darkest shades. The slope direction grid can be used effectively for advance topographical modeling such as identifying and characterizing areas of high water runoff and landslide, estimating the portion of land that will receive high and low solar illumination for agricultural research purposes. Figure 6 revealed that majority of the large flat surfaces are found in the south and southwestern part of the region. In the northern aspect of the terrain model, the slope is oriented to northwest and in the south it is facing the northeast.

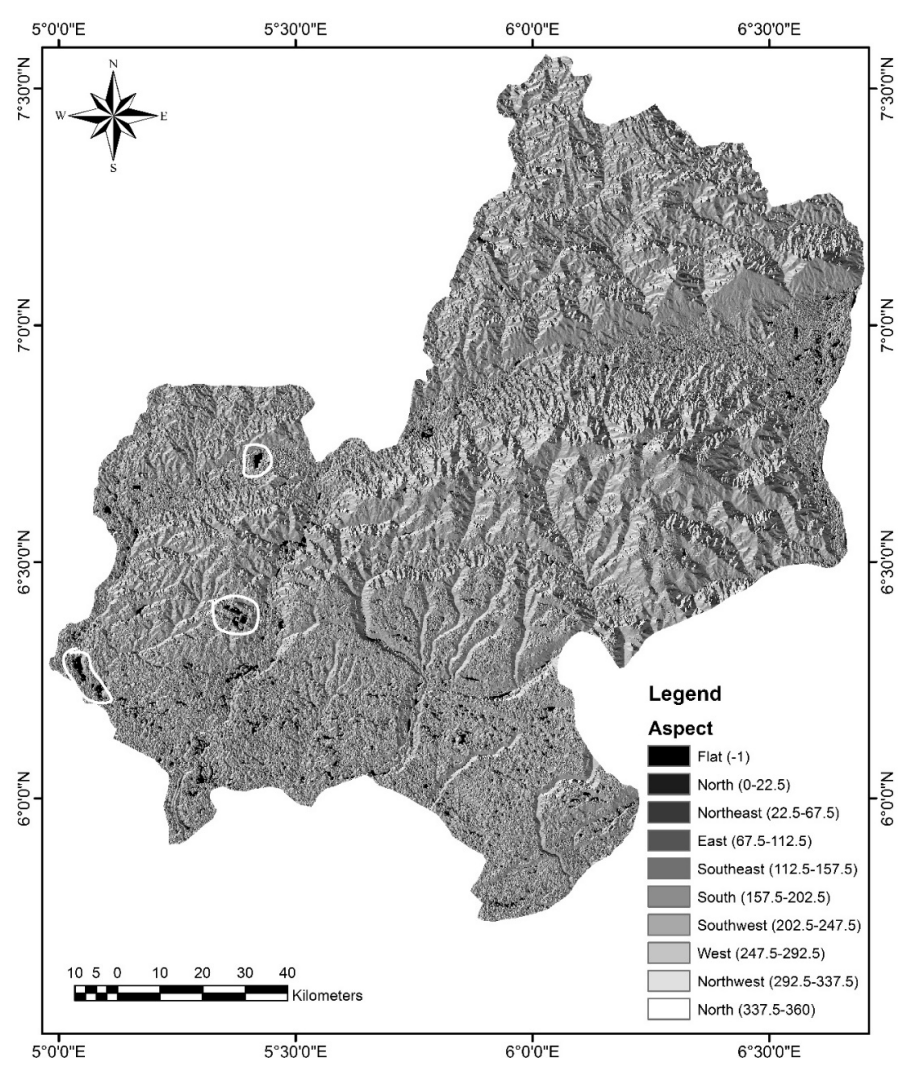

Figure 6. Aspect showing the slope direction of the region's terrain-the white cycles in the map highlight some of the flat surface with an aspect of -1

Slope at a point is calculated as the gradient of the plane formed by the vector connecting the left and right neighbours and the vector connecting the upper and lower neighbours of the pixel (Ganas et al., 2005). The slope displays the magnitude of surface structure inclination (i.e., the level of steepness). It output is an elevation grid containing slope values which range from $0^{\circ}$ to $90^{\circ}$ (i.e., from a level slope to a perfect vertical slope). Figure 7 shows that generally, the slope of the region decreases with distance from north to south. However, there is abrupt linear break in slope angle that created the large valley running from east to west. This slope has values ranging from roughly $5^{\circ}$ to $30^{\circ}$. In the grid image (Figure 7) steeper slopes are depicted with white colour while less steep slopes are shaded black. The slope aspect and slope gradient when combined are vital source of spatial information for overall landscape analysis and erosion modeling. Correspondingly, the highland areas also have steeper slope.

\subsection{Geovisualizing with Landscape Profiling}

Profile drawing for visualizing topographic shape and structure is a prominent method often employ by geomorphologists and geologists. This method is particularly helpful when the desired result is to visualize the pattern of mountain ranges, comparing the depth of two or more valleys and showing landscape variation in terms of ruggedness, height, steepness and plane. With GIS technology the extraction of landscape profile is automatic and the result has high level of precision compared to the manual method. This is because the data is 
in raster grid format which carries easting, northing and elevation $(\mathrm{X}, \mathrm{Y}, \mathrm{Z})$ values for each selected point or potential sample points.

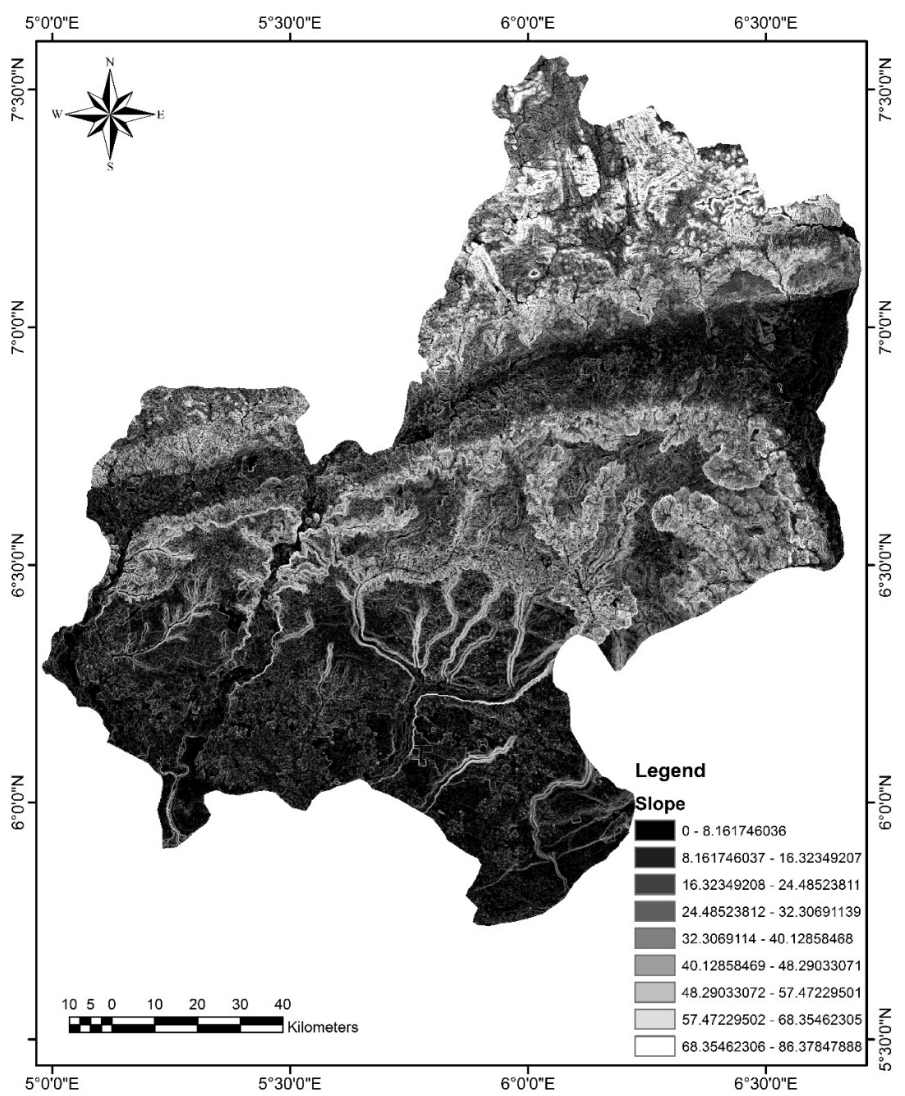

Figure 7. Slope gradient of the study region-areas in white have steeper slope than areas in black

In this study, profiles were drawn along distinct and suspicious landforms. Profiles were drawn from the northern to the southern part of the DEM (A-A), the eastern to western edges (B-B), northwestern to southeastern part of Benin region $(\mathrm{C}-\mathrm{C})$ where the state capital and largest city in the study area lies and along the edge of the Niger River floodplain (D-D) see Figure 8. The geographic coordinates of point X and point $\mathrm{Y}$ in each of the profiles are shown on the top left and top right of the profiles. Profile ' $A$ ' in Figure 8 confirms the topographic height hierarchy earlier identified with contour map. The first on the hierarchy is the northern highland which runs for about $63 \mathrm{~km}$ and has proximate height range of between 690 meters and 230 meters above sea level. The second is the central upland which runs for about $48 \mathrm{~km}$, its height range is between 320 meters to 164 meters. The third is the southern lowland which is about $65 \mathrm{~km}$ long and it height ranges between 125 meters to 23 meters above sea level.

\subsection{3-D Geovisualization}

3-D topographic surface of the study area was mapped and visualized using Global mapper GIS application. This GIS method has the ability to produce shade-free 3-D image of a landscape that gives same visual impression to all audience located in any viewing direction. The technique does not rely on aspect or sun direction to generate a surface, it uses the DEM information to simulate the real world (Figure 9). Since visualization is a powerful GIS tool for geographic analysis, such 3-D model will provide quick understanding, for stakeholders in landscape and physical environment profession, even for non-professional on the nature of the topography.

Figure 9 has clearly revealed an underlying suspicious structure in the terrain of the region (central valley). This will open a research frontier for geologists to investigate the reason behind such long depression that divided the region's highland into two. The impression that may likely come to mind is that the depression was an act of erosion or perhaps more advanced geologic processes of landform formation like fault-block Mountains or rift valley. 


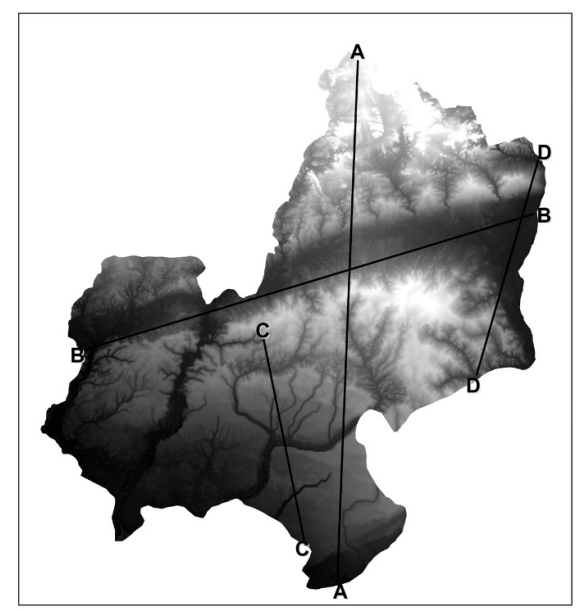

\section{A}

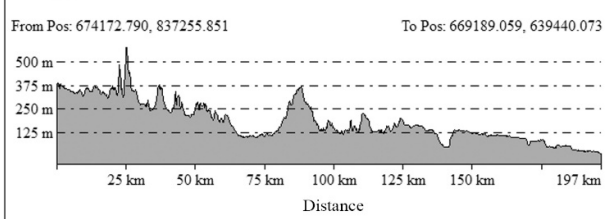

\section{B}

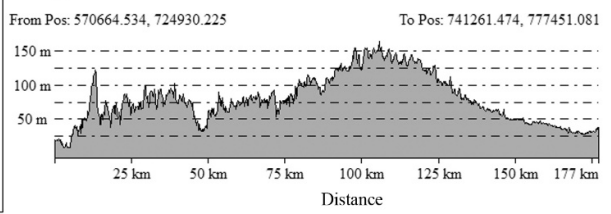

$\mathrm{C}$
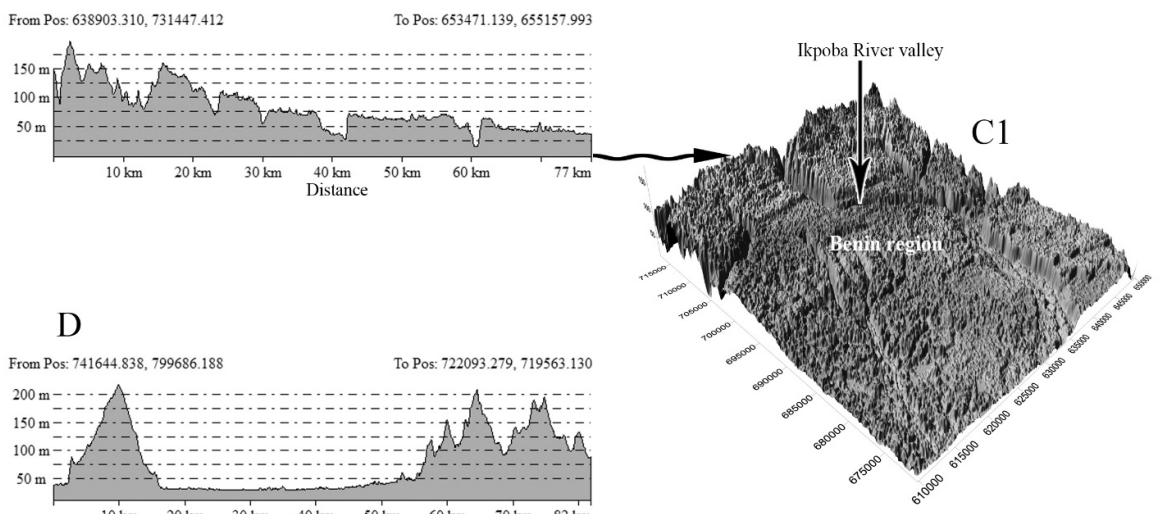

$\mathrm{D}$

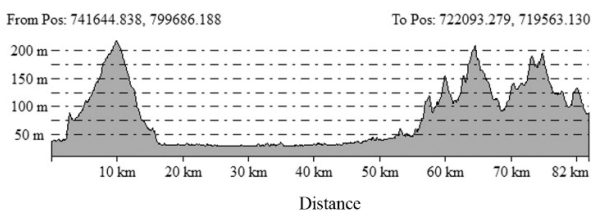

Figure 8. Four elevation profile lines drawn along distinct relief areas-top left is the DEM of the study region showing path profile lines on the surface (A, B, C and D). Bottom right is a 3-D grid of profile $\mathrm{C}(\mathrm{C} 1)$ depicting the landscape of Benin region

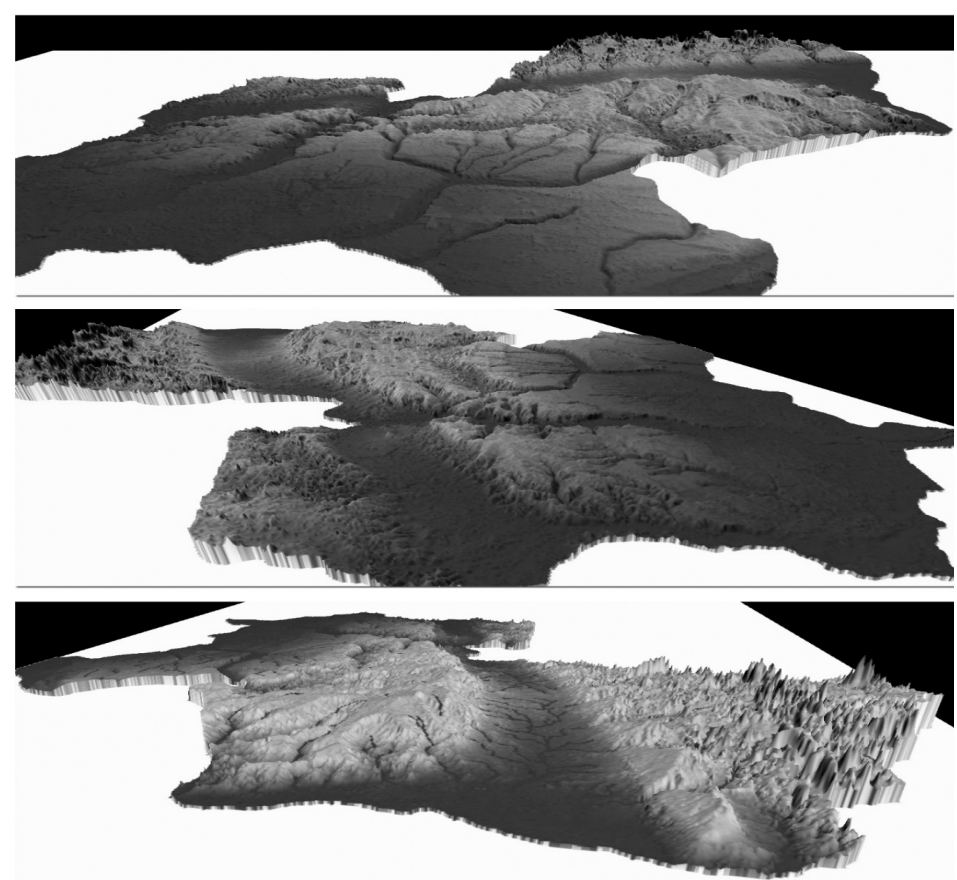

Figure 9. DEM-based 3-D landscape of Edo State from three perspectives 


\section{Conclusions}

This paper has demonstrated that GIS platform can effectively be used to map and geovisualize topographical data with regard to SRTM DEM-based raster. Over the year, the application of GIS technique in landscape modeling has been embraced by contemporary researchers in the physical environment disciplines. Developing a geographic visual model of any topography is a complex task that requires complex state-of-the-art technology if the goal is to achieve accurate result. This is because geographic datasets are complex in nature due to it spatial and temporal characteristics. Although, at the end of the nineteenth century, good quality topographic mapping existed for few regions of the world (part of Europe, North America, and India), the technology for producing such map could not meet the need of planners (Collier, 2002). Hence, there arise a need for technological advancement, and the adoption of new and promising methodology. GIS-based method offers the possibility of producing detailed large-scale topographical maps of all regions of the world in a time and cost-effective manner.

The map derivatives so generated in this paper clearly proves that using the SRTM data with appropriate GIS algorithms is a better substitute for conventional mapping and visualization techniques. This study demonstrates that from a single DEM data several topographical information can be extracted within a limited time frame. For example, the SRTM grid of the study region was able to automatically generate detailed hydrographic and physiographic features of the state. For the conventional mapping technique, numerous land survey data and aerial photographs are needed to generate similar amount of spatial information.

In addition, it was possible to produce a large-scale contour map of Edo State using the prescribed methodology and the 90 meter SRTM grid data. With the geovisualization capability it was much easier and convenient to zoom into any area for detailed and enlarged visual impression. The 2-D profiling and 3-D mapping and geovisualization techniques further justified the strength of this proposed topographical mapping procedure. From the DEM data and with the aid of the geovisualization algorithms it was possible to display and view the landscape of the region from multi-perspective without distorting the map or loss of any information. Other findings of this study include the categorization of the terrain of the state into high rugged north, the lowland south and an intermediate central region. Finally, a wide valley running from east to west was identified, and importantly, the valley created a distinct dichotomy between the north and central highlands.

It is evident from this study that the use of space technology to gather spatial data and computer softwares to manipulate, model and visualize such data is far more reliable, less time and cost consuming compared to the traditional or conventional survey and mapping methods. The numerous maps generated in this analysis constitute a comprehensive GIS database for advanced environmental modeling and assessment. The geovisualization capability of GIS makes topographic data easier to understand and interpret. Moreover, such quality information is vital for spatial planning and will contribute significantly to solving environmental and geomorphologic problems.

\section{References}

Adesina, J. G. (2007). Revision of the Nigerian 1:2,500 township maps in a GIS environment. In D. A. Musa, \& W. D. E. Wokoma (Eds.), Achieving Millennium Development Goals through Mapping (pp. 235-248).

Ajayi, G. E. (1992). Topographic mapping from satellite images: How feasible in developing countries? International Archives of Photogrammetry and Remote Sensing, 29(B4), 428-431.

Alpha, T. R., \& Winter, R. E. (1971). Quantitative physiographic method of landform portrayal. Canadian Cartographer, 8(2), 126-136. http://dx.doi.org/10.3138/374X-71K6-171T-W54R

Asikhia, O. M., \& Nkeki, F. N. (2013). DEM-based and geospatial hydro-physical modeling of the Niger-Benue River confluence in Nigeria. The Nigerian Journal of Cartographic and GIS, 8(1), 112-129.

Atilola, O. (1990). Revision and production of 1:50,000 maps using SPOT satellite imagery. Paper presented at the 25th Annual Conference of the Nigeria Institute of Surveyors, Kano, Nigeria.

Brewer, C. A. (2006). Basic Mapping Principles for Visualizing Cancer Data Using Geographic Information Systems (GIS). American Journal of Preventive Medicine, 20(2S), 25-36. http://dx.doi.org/10.1016/j.amepre.2005.09.007

Carabajal, C. C., \& Harding, D. J. (2006). SRTM C-band and ICESat laser altimetry elevation comparisons as a function of tree cover and relief. Photogrammetric Engineering and Remote Sensing, 72(3), 287-298. http://dx.doi.org/10.14358/PERS.72.3.287

Chiba, T., Kaneta, S., \& Suzuki, Y. (2008). Red relief image map: New visualization method for three 
dimensional data. The International Archives of the Photogrammetry, Remote Sensing and Spatial Information Sciences, 37(B2), 1071-1079.

Clarke, K. C., Mclafferty, S. L., \& Tempalski, B. J. (1996). On epidemiology and geographic information systems: A review and discussion of future directions. Perspectives, 2(2), 85-92.

Collier, P. (2002). The Impact on Topographic Mapping of Developments in Land and Air Survey: 1900-1939. Cartography and Geographic Information Science, 29(3), 155-174. http://dx.doi.org/10.1559/152304002782008440

Ehsani, H. A., \& Quiel, F. (2009). A semi-automatic method for analysis of landscape elements using shuttle radar topography mission and Landsat ETM+data. Computers and Geosciences, 35, 373-389. http://dx.doi.org/10.1016/j.cageo.2007.09.019

Fabiyi, O. O., Ige-Olumide, O., \& Enaruvbe, O. G. (2012). Spatial analysis of floodplains in Nigeria from spot satellite elevation data. In B. Ayeni, \& O. Fabiyi (Eds.), Geospatial technologies and digital cartography for national security, tourism and disaster management (pp. 239-252). Proceedings of joint conference of Geoinformation Society of Nigeria and Nigerian Cartographic Association.

Farr, T. G., \& Kobrick, M. (2000). Shuttle radar topography mission produces a wealth of data. AGU EOS, 81, 583-585. http://dx.doi.org/10.1029/EO081i048p00583

Ganas, A., Papadopoulos, G., \& Pavlides, S. B. (2001). The $7^{\text {th }}$ September 1999 Athens 5.9 Ms earthquake: remote sensing and digital elevation model inputs towards identifying the seismic fault. International Journal of Remote Sensing, 22(1), 191-196. http://dx.doi.org/10.1080/014311601750038938

Ganas, A., Pavlides, S., \& Karastathis, V. (2005). DEM-based morphometry of range-front escarpments in Attica, central Greece and its relation to fault slip rates. Geomorphology, 65(3), 301-319. http://dx.doi.org/10.1016/j.geomorph.2004.09.006

HEC-Geo Dozer. (2009). HEC-Geo Dozer user's manual version 1.0. US Army Corps of Engineers, Institute for water resources, hydrologic Engineering center, USA.

Hirano, A., Welch, R., \& Lang, H. (2003). Mapping from ASTER stereo image data: DEM validation and accuracy assessment. Journal of Photogrammetry \& Remote Sensing, 57, 356-370. http://dx.doi.org/10.1016/S0924-2716(02)00164-8

ICA-International Cartographic Association. (1973). Multilingual Dictionary of Technical Terms in Cartography. Franz Steiner Verlag, Wiesbaden.

Imhof, E. (1965). Kartographische Geldndedarstellung. Berlin: Walter de Gruyter. http://dx.doi.org/10.1515/9783110843583

Jordan, G., Csillag, G., Szucs, A., \& Qvarfort, U. (2003). Application of digital terrain modeling and GIS methods for the morphotectonic investigation of the Kali Basin, Hungary. Zeitschrift Fur Geomorphologie, 47, 145-169.

Lindsay, J. B. \& Creed, I. F. (2006). Distinguishing actual and artefact depressions in digital elevation data. Computers and Geosciences, 32(8), 1192-1204. http://dx.doi.org/10.1016/j.cageo.2005.11.002

Ludwig, R., Hellwich, O., Strunz, G., Roth, A., \& Eder, K. (2000). Applications of digital elevation models from SAR interferometry for hydrologic modelling. Photogrammetrie, Fernerkundung, Geoinformation, 2, 6-18.

Ludwig, R., \& Schneider, P. (2006). Validation of digital elevation models from SRTM X-SAR for applications in hydrologic modeling. Journal of Photogrammetry and Remote Sensing, 60, 339-358. http://dx.doi.org/10.1016/j.isprsjprs.2006.05.003

Michetti, A. M., Ferreli, L., Esposito, E., Porfido, S., Blumetti, A. M., Vittori, E., ... Roberts, G. P. (2001). Ground effects during the 9 September 1998, $\mathrm{Mw}=5.6$, Lauria earthquake and the seismic potential of the baseismicQ Pollino Region in Southern Italy. Seismological Research Letters, 71, 31-46. http://dx.doi.org/10.1785/gssrl.71.1.31

Nkeki, F. N. (2010). A study of the formidability of GIS-based system as an indispensable tool for solid wastes management: A case study of Benin metropolitan region. Benin Journal of Social Sciences, $18(1$ \& 2), 195-208.

Nkeki, F. N. (2013a). Living near high-voltage power lines: GIS-based modeling of the risk in Nigeria's Benin region. Applied GIS, 9(1), 1-20. 
Nkeki, F. N. (2013b). The risk of living near power lines: GIS modeling approach. Saarbruxken, Deutschland, Germany: Lambert Academic Publishing.

Nkeki, F. N., Henah, P. J., \& Ojeh, V. N. (2013). Geospatial techniques for the assessment and analysis of flood risk along the Niger-Benue Basin in Nigeria. Journal of Geographic Information System, 5(2), 123-135. http://dx.doi.org/10.4236/jgis.2013.52013

Obot, M. M. (2005). Topographic map revision: A case study of University of Uyo campus. In M. E. Ufuah, \& R. O. Olomo (Eds.), Cartography and GIS for Sustainable Solid Mineral Development in Nigeria (pp. 122-129).

Okpala-Okaka, C., \& Igbokwe, J. I. (2010). Revision of Nsukka N.E topographic map sheet 287 1:50,000 (1964) using Nigeria SAT-1 imagery. Nigerian Journal of Space Research, 7, 13-24.

Olaore, L. Y. S. (2007). An integrated use of SPOT XS and GPS data for updating topographic maps in a GIS environment. In D. A. Musa, \& W. D. E. Wokoma (Eds.), Achieving Millennium Development Goals through Mapping (pp. 90-119).

Ozah, P. A., \& Kufuniyi, O. (2008). Accuracy assessment of contour interpolation from 1:50,000 topographical maps and SRTM data for 1:25,000 topographical mapping. The International Archives of the Photogrammetry, Remote Sensing and Spatial Information Sciences, 37(B7), 1348-1353.

Petrie, G. (1997). The current situation in Africa regarding topographic mapping and map revision from satellite images. ITC Journal, 1, 49-63.

Rabus, B., Eineder, M., Roth, A., \& Bamler, R. (2003). The shuttle radar topography mission: A new class of digital elevation models acquired by spaceborne radar, Photogrammetric Engineering \& Remote Sensing, 57, 241-262. http://dx.doi.org/10.1016/S0924-2716(02)00124-7

Ufuah, M. E. (2002). The use of spot remote sensed data for the revision of Nigeria 1:50,000 topographic maps. In N. O. Uluocha, \& F. O. A. Dada (Eds.), Maps and Resource Management in Nigeria (pp. 98-108).

Ufuah, M. E. (2003). Non-revision of 1:50,000 topographic maps and its implications for sustainable development in Nigeria. Proceeding of the 21st International Cartographic Association Conference on Cartographic Renaissance (pp. 2579-2589). Durban, South Africa.

Valeriano, M. M., Kuplich, T. M., Storino, M., Amaral, B. D., Mendes, J. N., \& Lima, D. J. (2006). Modeling small watersheds in Brazilian Amazonia with shuttle radar topographic mission-90m data, Computers and Geosciences, 32(8), 1169-1181. http://dx.doi.org/10.1016/j.cageo.2005.10.019

Vysotsky, E. M., Vishnevskaya, E. A., \& Elobogoev, A. V. (2002). Neotectonic analysis of northern Lake Teletskoe using digital elevation modeling. Geologiya i Geofizika, 43(12), 1099-1106.

Wu, S., Li, J., \& Huang, H. G. (2007). Modeling the effects of elevation data resolution on the performance of topography-based watershed runoff simulation. Environmental Modelling and Software, 22(9), 1250-1260. http://dx.doi.org/10.1016/j.envsoft.2006.08.001

Yokoyama, R., Shirasawa, M., \& Pike, R. J. (2002). Visualizing topography by openness: A new application of image processing to digital elevation models. Photogrammetric Engineering and Remote Sensing, 68(3), 257-265.

\section{Copyrights}

Copyright for this article is retained by the author(s), with first publication rights granted to the journal.

This is an open-access article distributed under the terms and conditions of the Creative Commons Attribution license (http://creativecommons.org/licenses/by/3.0/). 